\title{
Erratum to: Books Received in 2007
}

Published online: 13 May 2011

(C) Springer Science+Business Media B.V. 2011

\section{Erratum to: J Gen Philos Sci DOI 10.1007/s10838-007-9052-7}

Due to a mistake, this 2007 file needed to be published in the 2011 volume, but is not relevant to our readers anymore. 